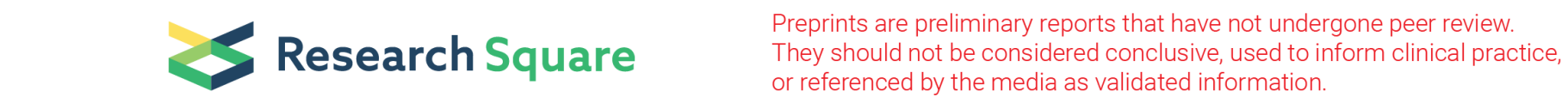

\title{
Study of radiation damage with the radiation workers by low dose irradiation
}

Gang Liu ( $\square$ Igscfll@163.com)

gansu provincial center for disease control and prevention

Ye Li

gansu provincial center for disease control and prevention

\section{Research}

Keywords: radiologic worker, dose-effect relation, Personal dose, Peripheral blood cell, crystalline lens, Chromosome aberration analysis

Posted Date: May 29th, 2020

DOI: https://doi.org/10.21203/rs.3.rs-30760/v1

License: 두 (i) This work is licensed under a Creative Commons Attribution 4.0 International License. Read Full License 


\section{Abstract}

Objective

To explore the sensitivity index of radiation injury of radiation workers was analyzed and investigate whether the body changes and radiation doses of workers exposed to low-dose radiation have a dose-effect relationship.

Methods

The occupational health monitoring data of radiology staff were analyzed by retrospectively.

Results

Individual dose monitoring data, interventional radiology workers had the highest average cumulative annual dose, $0.86 \mathrm{mSv}$. Lens opacity has a high detection rate, Compared with the control group, the lymphocyte count was increased. Annual cumulative dose reached $2.04 \mathrm{mSv}$, and single cycle average dose reached $1.62 \mathrm{mSv}$, dicentric chromosome was detected.

Conclusions

Radiation workers have certain radiation damage, and the focus is on those engaged in interventional radiology. The chromosome aberration rate was highest in people with more than 20 years of working life. Annual cumulative dose reached $2.04 \mathrm{mSv}$, and single cycle average dose reached $1.62 \mathrm{mSv}$, dicentric chromosome was detected, it suggests that the chromosome aberration analysis is an important index in occupational health monitoring of radiological workers.

\section{Introduction}

Following the discovery of X-rays in 1895 by German physicist Wilhelm Conrad Röntgen and of radioactivity the following year by French physicist Henri Becquerel, medical, industrial, and military uses of radiation technology were developed that eventually led to a marked increase in human population exposure to ionizing radiation. With the wide application of radiation technology in the medical field, more than $70 \%$ of the radiation comes from the medical application of radiation.

Radiation injury, tissue damage or changes caused by exposure to ionizing radiation-namely, gamma rays, X-rays, and such high-energy particles as neutrons, electrons, and positrons. Sources of ionizing radiation may be natural (e.g., radioactive substances such as the element radium or the radioisotopes potassium-40 and carbon-14) or man-made (X-ray machines, nuclear reactors, particle accelerators, nuclear weapons, etc.).

Through the displacement of electrons (ionization), ionizing radiation effectively disrupts molecular bonds. In living organisms, such disruption can cause extensive damage to cells and their genetic material. A characteristic type of DNA damage produced by ionizing radiation, even by a single radiation track through a cell, involves closely spaced, multiple lesions that compromise cellular DNA repair mechanisms. Although most of the cells sustaining such radiation-induced damage may be eliminated by damage response pathways, some cells are capable of escaping these pathways, propagating, and eventually undergoing malignant transformation, a crucial step in cancer development.(1)

Cancer risk is increased roughly in proportion to the amount of energy deposited in tissue (radiation dose, usually quantified in units of gray [Gy] or milligray [mGy], where 1 Gy corresponds to 1 joule of energy per kilogram of tissue). However, organs and tissues differ in their sensitivity to radiation carcinogenesis (cancer-causing ability). Cancer risk further varies by type of ionizing radiation, by gender, by age at exposure, by age and time following exposure, and by lifestyle factors, such as reproductive history and exposure to other carcinogens (e.g., tobacco smoke). On average, the bulk of radiation dose to individuals comes from natural background sources that have changed little over the span of human existence. Assessment of the health impact of ionizing radiation requires an understanding of the interactions of radiation with living cells and the subsequent reactions that lead to injury. $(2,3)$

The biomedical effects of ionizing radiation have been investigated more thoroughly than those of any other environmental agent. Evidence that harmful effects may result from small amounts of such radiation has prompted growing concern about the hazards that may be associated with low-level irradiation from the fallout of nuclear weapons, medical radiography, nuclear power plants, and other sources.

Screening from 2016 to 2017 based on the radiation exposure dose of radiation workers, through the statistical analysis to investigate the interventional radiology, diagnostic radiology, radiotherapy, industrial flaw detection, the different type of work such as nuclear medicine, 
different length of service and whether there is any contact between the average dose dose - effect relationship, provide the basis for provide the corresponding intervention measures.

\section{Material And Method}

A total of 976 radiological workers who underwent occupational health monitoring were randomly selected as subjects. The average age was $(37.52 \pm 9.84)$ years, and the average length of service was $(12.11 \pm 9.96)$ years. Which work in the X-ray diagnosis of 560 cases of radiation workers, $57.38 \%$ (men and women than 1.33:1), radiation therapy, 155 cases, $15.88 \%$ (men and women than $0.96: 1$ ), 158 cases of interventional treatment accounted for $16.19 \%$ (men and women than $2.01: 1$ ), nuclear medicine 60 cases, $6.15 \%$ (men and women than 2.33:1), industrial flaw detection 43 cases, $4.41 \%$ (men and women than 4.38:1).There was no significant difference in age, gender and length of service among the subjects $(P>0.05)$.

\section{Clinical Examination}

According to the occupational health management measures for radiation workers, the examination contents include general medicine, neurology, dermatology and ophthalmology. The lens was fully dilated with compound topic amide eye drops, and the lens was examined under slit lamp microscope.

\section{Laboratory Examination}

WBC and PLT were the main indicators of peripheral blood. Venous blood was collected and analyzed by MEDONIC CA620, a fully automatic hematomata. Personal dose monitoring of radiation can be done by field monitoring or TLD monitoring. Cytogenetic test: analysis of chromosomal aberration rate and micronucleus rate of peripheral blood lymphocytes, chromosomal aberration rate and micronucleus rate of peripheral blood lymphocytes by 1640 culture medium for $48 \mathrm{~h}$ and $72 \mathrm{~h}$ respectively. The chromosome aberration rate was analyzed for 200 mitotic phases per person, and the lymphocyte micronucleus rate was analyzed for 1000 lymphocytes per person. (5-9)

\section{Results Determination}

Personal dosimetry was performed on the personal dosimeter worn by the radiological workers. The blood routine results were determined according to GB 98-2002 health standards for radiological workers. Leucocyte exceeding $(4.0 \sim 11.0) \times 10^{9} / \mathrm{L}$ and platelet exceeding $(100 \sim$ $300) \times 10^{9} / \mathrm{L}$ are abnormal. The ocular lens opacification was regarded as abnormal. Chromosome aberration rate and lymphocyte micronucleus rate; Ophthalmic features were characterized by ocular lens opacification (focusing on vacuoles or punctures in the posterior sub capsular cortex was considered opacification).

\section{Statistical analysis}

SPSS 20.0 was used for data analysis, and chi-square test was used for rate comparison. $\mathrm{P}<0.05$ was considered statistically significant.

\section{Result}

\section{Mean annual cumulative dose}

Radiological workers of different types of work: interventional radiology workers: $0.86 \mathrm{mSv}$, radiological diagnosis: 0.37 mSv, radiotherapy: $0.13 \mathrm{mSv}$, industrial inspection: $0.33 \mathrm{mSv}$, and nuclear medicine: $0.44 \mathrm{mSv}$.

The detection rates of leukocyte and platelet decrease, lens opacity and lymphocyte micronucleus were compared.

There was no significant difference in the leukocyte lowering rate among different groups $(P>0.05)$.

The difference in platelet lowering rates among radiological workers engaged in diagnostic and therapeutic radiology was statistically significant. There was a statistically significant difference in platelet lowering rates between the radiosurgery and interventional therapy workers.

The difference in the rate of lens opacity was statistically significant. Using the radiotherapists as the control group, it was found that there was a difference in the detection rate of lens turbidity among the radiotherapists engaged in interventional therapy, nuclear medicine and 
industrial inspection, and the difference was statistically significant. See Table 1

Table 1

comparison of leucocyte and platelet decrease, lens opacity detection rate and lymphocyte micronucleus rate in radiological workers of different types of work

\begin{tabular}{|c|c|c|c|c|c|c|c|c|c|c|}
\hline \multirow[t]{2}{*}{ Group } & \multirow[t]{2}{*}{$\begin{array}{l}\text { Average } \\
\text { annual } \\
\text { cumulative } \\
\text { dose(mSv) }\end{array}$} & \multirow[t]{2}{*}{ samples } & \multicolumn{2}{|c|}{$\begin{array}{l}\text { WBC } \downarrow \\
<4 \times 10^{9} / L\end{array}$} & \multicolumn{2}{|c|}{$\begin{array}{l}\text { PLT } \downarrow \\
<100 \times 10^{9} / \mathrm{L}\end{array}$} & \multicolumn{2}{|c|}{$\begin{array}{l}\text { Lens opacity } \\
\text { detection rate }\end{array}$} & \multicolumn{2}{|c|}{$\begin{array}{l}\text { Micronucleus rate } \\
\text { of lymphocytes }\end{array}$} \\
\hline & & & samples & rate(\%) & samples & rate(\%) & samples & rate(\%) & samples & rate(\%) \\
\hline $\begin{array}{l}\text { Interventional } \\
\text { radiology }\end{array}$ & 0.86 & 158 & 14 & 8.86 & 3 & 1.9 & 22 & 13.92 & 35 & 22.15 \\
\hline Diagnostic radiology & 0.37 & 560 & 57 & 10.18 & 19 & 3.39 & 77 & 13.75 & 153 & 27.32 \\
\hline Radiation therapy & 0.13 & 155 & 15 & 9.58 & 11 & 7.1 & 5 & 3.23 & 44 & 28.39 \\
\hline Industrial application & 0.33 & 43 & 5 & 11.63 & 4 & 9.3 & 7 & 16.28 & 7 & 16.28 \\
\hline Nuclear medicine & 0.44 & 60 & 3 & 5.00 & 4 & 6.67 & 9 & 15.00 & 12 & 20.00 \\
\hline Total & - & 976 & 94 & 9.63 & 41 & 4.2 & 120 & 12.30 & 251 & 25.72 \\
\hline
\end{tabular}

Groups according to working-age. There was no statistically significant difference between the reduction rate of WBC and the reduction rate of PLT among the radiological age group(P>0.05);The lymphocyte micronucleus rate was in groups 0-10 and 10-20.10 20 groups were compared with: $>20$ groups. Group $0 \sim 10$ and group $>20 \mathrm{PP}<0.01 \rrbracket$,there were significant differences among different age groups; The workers with more than 20 years of working experience had the highest rate of chromosomal aberrations. See Table 2

Table 2

comparison of blood abnormalities, lens opacity and micronucleus effects in radiological workers with different working ages

\begin{tabular}{|c|c|c|c|c|c|c|c|c|c|c|c|}
\hline \multirow[t]{2}{*}{$\begin{array}{l}\text { working- } \\
\text { age }\end{array}$} & \multirow[t]{2}{*}{ Samples } & \multicolumn{2}{|c|}{$\begin{array}{l}\text { WBC } \downarrow \\
<4 \times 10^{9} / \mathrm{L}\end{array}$} & \multicolumn{2}{|c|}{$\begin{array}{l}\text { PLT } \downarrow \\
<100 \times 10^{9} / \mathrm{L}\end{array}$} & \multicolumn{2}{|c|}{$\begin{array}{l}\text { Lens opacity } \\
\text { detection rate }\end{array}$} & \multicolumn{2}{|c|}{$\begin{array}{l}\text { Micronucleus rate of } \\
\text { lymphocytes }\end{array}$} & \multicolumn{2}{|c|}{$\begin{array}{l}\text { Chromosome } \\
\text { aberration rate }\end{array}$} \\
\hline & & Samples & $\begin{array}{l}\text { Rate } \\
(\%)\end{array}$ & Samples & Rate(\%) & Samples & Rate(\%) & Samples & Rate(\%) & Samples & Rate(\%) \\
\hline $0 \sim 10$ & 500 & 49 & 9.80 & 18 & 3.6 & 35 & 7.00 & 128 & 25.2 & 12 & 2.40 \\
\hline 10 20 & 270 & 24 & 8.89 & 11 & 4.07 & 35 & 12.96 & 42 & 15.56 & 4 & 1.48 \\
\hline$>20$ & 236 & 21 & 8.90 & 12 & 5.08 & 40 & 16.95 & 72 & 30.51 & 8 & 3.39 \\
\hline Total & 976 & 94 & 9.63 & 41 & 4.2 & 120 & 12.30 & 251 & 25.72 & 24 & 2.46 \\
\hline
\end{tabular}

Peripheral radiation workers from 2015 to 2017 as test results, the radiation workers as the control group, there was no statistically significant differences between groups $(P>0.05)$. See Table 3

Table 3

analysis of peripheral blood examination results of radiological workers from 2015 to 2017

\begin{tabular}{|lllllll|}
\hline The years & Sample & WBC $\times 10^{9} / \mathrm{L}$ & $\mathrm{RBC} \times 10^{12} / \mathrm{L}$ & $\mathrm{PLT} \times 10^{9} / \mathrm{L}$ & \multicolumn{2}{l}{ Lymphocyte count } \\
& & & & & $\times 10^{9} / \mathrm{L}$ & $\begin{array}{c}\text { Neutrophil count } \\
\times 10^{9} / \mathrm{L}\end{array}$ \\
\hline 2015 & 2013 & $5.61 \pm 1.39$ & $4.92 \pm 0.45$ & $176.92 \pm 60.32$ & $1.74 \pm 0.52$ & $3.44 \pm 1.11$ \\
\hline 2016 & 1164 & $5.84 \pm 1.43$ & $4.78 \pm 0.43$ & $187.87 \pm 54.51$ & $1.83 \pm 0.50$ & $3.55 \pm 1.19$ \\
\hline 2017 & 2204 & $5.82 \pm 1.55$ & $4.79 \pm 0.44$ & $190.44 \pm 60.55$ & $1.81 \pm 0.53$ & $3.54 \pm 1.31$ \\
\hline Control group & 1093 & $5.67 \pm 1.43$ & $4.78 \pm 0.49$ & $183.84 \pm 58.09$ & $1.69 \pm 0.51$ & $3.51 \pm 1.17$ \\
\hline
\end{tabular}

General radiation staff of provincial and municipal hospitals, Interventional radiology staff of provincial and municipal hospitals, Nuclear medicine staff of provincial and municipal hospitals, County - level hospital general radiation staff, Interventional radiology staff of Countylevel hospitals, township hospital general radiation staff, Average annual dose: $0.64 \mathrm{mSv} \otimes 2.08 \mathrm{mSv} \varangle 0.96 \mathrm{mSv} \otimes 0.79 \mathrm{mSv} \otimes 1.06 \mathrm{mSv} \varangle 0.52 \mathrm{mSv} \square$ 
$0.56 \mathrm{mSv} \square$ Interventional radiology staff of County-level hospitals,Average annual dose: $1.06 \mathrm{mSv} \square$ The difference was statistically significant by $\mathrm{X}^{2}$ test $(P<0.05)$. See Tables 4 and 5

Table 4

detection of abnormal white blood cells and platelets and lens opacity in radiological workers

\begin{tabular}{|c|c|c|c|c|c|}
\hline Group & $\begin{array}{l}\text { Annual average } \\
\text { dose (mSv) }\end{array}$ & Number & $\begin{array}{l}\text { Low white blood } \\
\text { cell count } \\
(<4 \times 109 / \mathrm{L})\end{array}$ & $\begin{array}{l}\text { Low platelet } \\
\text { count } \\
(<100 \times \\
\left.10^{9} / \mathrm{L}\right)\end{array}$ & Phacoscotasmus \\
\hline $\begin{array}{l}\text { General radiation staff of provincial and } \\
\text { municipal hospitals }\end{array}$ & 0.64 & 148 & $8(5.41)$ & $4(2.70)$ & $40(27.03)$ \\
\hline $\begin{array}{l}\text { County - level hospital general radiation } \\
\text { staff }\end{array}$ & 2.08 & 6 & 2(33.33) & $0(0.00)$ & $1(16.67)$ \\
\hline $\begin{array}{l}\text { General radiation staff of provincial and } \\
\text { municipal hospitals }\end{array}$ & 0.96 & 478 & $37(7.74)$ & $12(2.51)$ & 103(21.55) \\
\hline $\begin{array}{l}\text { General radiation staff of provincial and } \\
\text { municipal hospitals }\end{array}$ & 0.79 & 185 & $11(5.95)$ & 2(1.08) & $53(28.65)$ \\
\hline $\begin{array}{l}\text { General radiation staff of provincial and } \\
\text { municipal hospitals }\end{array}$ & 1.06 & 28 & $1(3.57)$ & $0(0.00)$ & $7(25.00)$ \\
\hline Township hospital general radiation staff & 0.52 & 52 & $4(7.69)$ & $1(1.92)$ & $16(30.77)$ \\
\hline Industrial flaw detection & 0.56 & 14 & $1(7.14)$ & $1(7.14)$ & $3(21.43)$ \\
\hline Total & - & 911 & $64(7.02)$ & $20(2.20)$ & $223(24.45)$ \\
\hline
\end{tabular}

Table 5

detection of white blood cell and platelet decrease and lens opacity in county level general release and county level interventional workers

\begin{tabular}{|lllll|}
\hline Group & Number & Low white blood cell count & Low platelet count & Phacoscotasmus \\
& & $\left(<4 \times 10^{9} / \mathrm{L}\right)$ & $2(1.08)$ & $53(28.65)$ \\
\hline General radiation & 185 & $11(5.95)$ & $0(0.00)$ & $1(16.67)$ \\
\hline County - level hospital general radiation staff & 6 & $2(33.33)$ & $(\mathrm{L})$ \\
\hline
\end{tabular}

\section{Chromosome Aberration Analysis}

Chromosomal aberrations were analyzed in 3,025 radiological workers, the results are shown in Table 6.

Table 6

the relationship between dicentric chromosomes and individual dose monitoring data was detected

\begin{tabular}{|llll|}
\hline Group & Number & Average annual dose ( $\mathrm{mSv})$ & Single maximum average dose( mSv) \\
\hline Detected dicentric chromosome & 11 & 2.04 & 1.62 \\
\hline Undetectable dicentricchromosome & 189 & 0.08 & 0.13 \\
\hline
\end{tabular}

Individual dose monitoring for radiation workers, four times a year, three months at a time.

The radiation worker received a dose of $2.04 \mathrm{mSv}$, dicentric chromosome was detected. Single maximum average dose is 1.62 mSv, dicentric chromosome was detected.

This suggests that the chromosome aberration analysis is an important index in occupational health monitoring of radiological workers.

\section{Discussion}

The effects of long-term low dose ionizing radiation on human body are attracting more and more attention. It is generally believed that longterm and small doses of occupational radiation can lead to radiation workers in all aspects of the damage, in which the division of vigorous, 
metabolic vigorous cells are more sensitive to radiation. Therefore, the hematopoietic system of human body is the sensitive target system of radiation, and the change of peripheral blood image is the early manifestation of radiation damage.

Studies have shown that peripheral blood lymphocytes are more sensitive to ionizing radiation, resulting in decreased white blood cell count, lens opacity, and increased micronucleus rate and chromosome aberration rate of peripheral blood lymphocytes. Many scholars have analyzed and discussed the body damage caused by long-term low-dose irradiation of radiation workers (mainly taking four indexes of WBC count, PLT count, lens opacity detection rate, chromosome aberration rate and micronucleus detection rate as the observation and analysis indexes), but the results are not consistent. (10-12) This study proved that the radiation effect did not show obvious regularity with the change of radiation dose among the radiation workers. Although there were differences in the effects, the differences were not statistically significant, and the dose-effect relationship among the radiation workers in was not found.

The lymphocyte micronucleus rate was in groups $0-10$ and 10-20.10 20 groups were compared with: > 20 groups. $0 \sim 10$ groups and $20>$ groups $(P<0.01)$, and there was a significant difference among the age groups. The chromosome aberration rate was highest in people with more than 20 years of working life.

In summary, the workers with a longer working-age have longer working hours and heavy workload, which leads to prolonged cumulative exposure time and increased exposure dose, which may aggravate the radiation damage of the body.

The lymphocyte count was higher than that of the control group. Whether there is a certain excitation effect of low dose irradiation on the immune system needs further discussion.

\section{Conclusion}

Radiation workers have certain radiation damage, and the focus is on those engaged in interventional radiology. The chromosome aberration rate was highest in people with more than 20 years of working life. Annual cumulative dose reached $2.04 \mathrm{mSv}$, and single cycle average dose reached $1.62 \mathrm{mSv}$, dicentric chromosome was detected, it suggests that the chromosome aberration analysis is an important index in occupational health monitoring of radiological workers.

The lymphocyte count was higher than that of the control group, whether there is a certain excitation effect of low dose irradiation on the immune system needs further discussion.

Setting of new regulatory exposure limits, improving workers' radiation dosimetry, administration of stable iodine, running an occupational health tracking system, and improving occupational medicine and preventative care. Those interventions were not only vital for preventing unnecessary radiation, but also for managing other general health issues such as mental health, heat illness and infectious diseases.

\section{Declarations}

\section{Funding:}

This study was funded by the Lanzhou science and technology bureau (2018-1-127) and Gansu provincial health commission (GSWSKY2018-48).

\section{*Corresponding authors:}

Dr. Gang Liu,

Fax: + 86 0931-8264944

E-mail: Igscfll@163.com

\section{Conflict of interest}

The authors declare that they have no conflict of interest.

\section{Human and animal rights}

The research was approved by the Bioethics Committee at the Gansu provincial center for disease control and prevention. This article does not contain any studies with animals performed by any of the authors. 


\section{ETHICS APPROVAL AND CONSENT TO PARTICIPATE}

Not applicable

\section{Consent for publication}

Not applicable

\section{Authors' contributions}

Gang Liu and Ye Li were a major contributor in writing the manuscript.

All authors read and approved the final manuscript. Gang Liu and Ye Li are Co-first author.

\section{Availability of data and materials}

Not applicable『Protect personal privacy $\llbracket$

\section{References}

1. Fachin AL, Mello SS, Sandrin-Garcia P, et al. Gene expression profiles in radiation workers occupationally exposed to ionizing radiation. J Radiat Res. 2009 Jan;50(1):61-71.

2. International Commission on Radiological. The 2007 Recommendations of the International Radiation Protection Committee. Beijing: Atomic Energy Press; 2008.

3. Vaurijoux A, Gruel G, Pouzoulet F, et al. Strategy for population triage based on dicentric analysis. Radiat Res. 2009;171(5):541-8.

4. Chen DQ, Zhang CY. A simple and convenient method for gaining pure populations of lymphocytes at the first mitotic division in vitro. Mutat Res. 1992;282(3):227-9.

5. National Health and Family Planning Commission of PRC. GBZ/T248-2014 Test and Assessment of Chromosomal Aberrations on Occupational Health Examinations for Radiation Workers. Beijing: Standards Press of China; 2014.

6. Wang Y, Xu C, Du LQ, et al. Evaluation of the comet assay for assessing the dose-response relationship of DNA damage induced by ionizing radiation. Int J Mol Sci. 2013;14(11):22449-61.

7. Wang H, Liu Q, Wan D, et al. BioDoser: improved dose-estimation software for biological radiation dosimetry. Comput Methods Programs Biomed. 2012;108(1):402-6.

8. Cytogenetic Dosimetry. Applications in Preparedness for and Response to Radiation Emergencies. Vienna: IAEA; 2011.

9. National Health and Family Planning Commission of PRC. GBZ105-2017 Diagnostic Criteria for Chronic Radiation SicknessFrom External Exposure. Beijing: Standards Press of China; 2017.

10. Li, Qinghai. Zhou xiaoming.Analysis of health monitoring results of radiation workers in Wuxi medical system in 2010 [J].China radiation health, 2012, $21(2: 187-188)$

11. Lay zh, hang $\mathrm{k} \mathrm{J}$, Yang $\mathrm{h} \mathrm{f}$, et al. Application of peripheral blood cytogenetic index in radiation damage assessment of radiological workers [J]. Henan journal of preventive medicine, 2016, 27 (10): 721-727. (In Chinese with English abstract).

12. Lay Zhuang Hua, lug jianchao, zhang kejian, et al.Exposure to industry: analysis of radiation injury sensitivity index of radiological workers [J]. China radiation health. 2016, 25 (3): 312-315. 